\title{
A emergência do livro didático de Filosofia no período de 1980 a 1990
}

\author{
The emergence of the Philosophy textbook from 1980 to 1990 \\ La aparición del libro de texto de Filosofía de 1980 a 1990
}

Recebido: 17/02/2021 | Revisado: 28/02/2021 | Aceito: 01/03/2021 | Publicado: 08/03/2021

\author{
Raquel Brum Sturza \\ ORCID: https://orcid.org/0000-0002-8229-9178 \\ Universidade Federal de Santa Maria, Brasil \\ E-mail: raquelsturza@hotmail.com \\ Elisete Medianeira Tomazetti \\ ORCID: https://orcid.org/0000-0002-4979-7415 \\ Universidade Federal de Santa Maria, Brasil \\ E-mail: elisetem2@gmail.com
}

\begin{abstract}
Resumo
Este artigo é um recorte da pesquisa 'Livros didáticos de Filosofia no Brasil (1980-1990): um estudo sobre proveniências e modos de ensinar Filosofia', realizada no curso de Mestrado do Programa de Pós-Graduação em Educação da Universidade Federal de Santa Maria. Tem por objetivo discorrer sobre os livros didáticos de Filosofia produzidos no Brasil nas décadas de 1980 e 1990. Problematizamos este período histórico brasileiro, de modo a compreender os elementos que se tornaram condições para que os livros didáticos, em geral, e os livros didáticos de filosofia, em especial, pudessem emergir com força e relevância no ensino escolar de filosofia no Brasil. Para tanto, o estudo se aproxima de uma perspectiva genealógica de Michel Foucault (2015), como a escrita de uma história que recusa a perfeição das origens, reconhecendo os acontecimentos como tramas discursivas, que se cruzam e entrecruzam em movimentos e forças constantes que formam e transformam o contexto. Resulta da investigação que a emergência do livro didático de Filosofia é condicionada as forças em jogo que se tramaram nos seguintes períodos: o fim da Ditadura Militar; o processo de redemocratização (1980); o processo de massificação do ensino (1990); as lutas e os embates para o retorno do ensino de Filosofia aos currículos do segundo grau/ensino médio e a publicação da Lei 9.349 de 1996.
\end{abstract}

Palavras-chave: Livro didático de filosofia; Condições históricas; Ensino.

\begin{abstract}
This article is an excerpt from the research 'Philosophy textbooks in Brazil (1980-1990): a study on the origins and ways of teaching Philosophy', carried out in the Master's course of the Graduate Program in Education at the Federal University of Santa Maria. It aims to discuss the Philosophy textbooks produced in Brazil in the 1980s and 1990s. We problematize this Brazilian historical period, in order to understand the elements that have become conditions for textbooks, in general, and textbooks of philosophy, in particular, could emerge with strength and relevance in school philosophy teaching in Brazil. To this end, the study approaches a genealogical perspective by Michel Foucault (2015), as the writing of a story that refuses the perfection of the origins, recognizing the events as discursive plots, which intersect and intertwine in constant movements and forces that form and transform the context. It appears from the investigation that the emergence of the Philosophy textbook is conditioned by the forces at play that were plotted in the following periods: the end of the Military Dictatorship; the process of redemocratization (1980); the process of massification of teaching (1990); the struggles and struggles for the return of Philosophy teaching to high school / high school curricula and the publication of Law 9.349 of 1996.
\end{abstract}

Keywords: Philosophy textbook; Historical conditions; Teaching.

\section{Resumen}

Este artículo es un extracto de la investigación 'Libros de texto de Filosofía en Brasil (1980-1990): un estudio sobre los orígenes y formas de enseñar Filosofía', realizada en la Maestría del Programa de Posgrado en Educación de la Universidad Federal de Santa María. . Tiene como objetivo discutir los libros de texto de Filosofía producidos en Brasil en las décadas de 1980 y 1990. Problematizamos este período histórico brasileño, para comprender los elementos que se han convertido en condiciones para los libros de texto, en general, y los libros de texto de filosofía, en particular, que podrían surgir con fortaleza y relevancia en la enseñanza de la filosofía escolar en Brasil. Para ello, el estudio aborda una perspectiva genealógica de Michel Foucault (2015), como la redacción de un relato que rechaza la perfección de los orígenes, reconociendo los hechos como tramas discursivas, que se entrecruzan y entrelazan en constantes movimientos y fuerzas que forman y forman transformar el contexto. De la investigación se desprende que la aparición del texto de Filosofía está condicionada por las fuerzas en juego que se tramaron en los siguientes 
períodos: el fin de la Dictadura Militar; el proceso de redemocratización (1980); el proceso de masificación de la docencia (1990); las luchas y luchas por el retorno de la enseñanza de la Filosofía a los planes de estudio de la escuela secundaria / preparatoria y la publicación de la Ley 9.349 de 1996.

Palabras clave: Libro de texto de filosofía; Condiciones históricas; Enseñanza.

\section{Introdução}

Este artigo é um recorte da pesquisa 'Livros didáticos de Filosofia no Brasil (1980-1990): um estudo sobre proveniências e modos de ensinar Filosofia’ (Sturza, 2019), realizada no curso de Mestrado do Programa de Pós-Graduação em Educação da Universidade Federal de Santa Maria.

Tem como objetivo discorrer sobre os livros didáticos de Filosofia produzidos e utilizados nas décadas de 1980 e 1990, no Brasil. Para tal, elencamos, alguns desses acontecimentos que julgamos terem sido forças importantes para sua emergência no período.

\section{Metodologia}

Em termos metodológicos, o estudo se aproxima de uma perspectiva pós-estruturalista, de caráter genealógico de Michel Foucault (2015), que, a partir de Nietzsche, a considera como a escrita de uma história que recusa a perfeição das origens, reconhecendo os acontecimentos como tramas discursivas, que se cruzam e entrecruzam em movimentos e forças constantes que formam e transformam o contexto.

O genealogista revira os papéis empoeirados com o intuito de recompor a emergência dos acontecimentos, tendo como direção não a busca da origem, a essência verdadeira das coisas, que supostamente se revelaria após o desvelamento metódico, mas seu trabalho visa ao reconhecimento das manobras, das disputas, da pluralidade dos erros em torno da fabricação de valores, da moral, do conhecimento, das subjetividades. Nesse sentido, o genealogista persegue seu objeto em um contínuo temporal para evidenciar suas descontinuidades (Sturza, 2019, p. 34).

A genealogia não se funda, mas agita o que se percebia imóvel; ela fragmenta o que se pensava unido; mostra a heterogeneidade do que se imaginava em conformidade consigo mesmo. As relações de poder e saber são o foco da genealogia, com efeito, emergem os novos acontecimentos. Trata-se de observar as heterogeneidades, ou seja, realizar a análise da proveniência e emergência, e não a busca de origens.

A proveniência permite reencontrar, sob o aspecto único de um caráter ou de um conceito, a proliferação dos acontecimentos através dos quais (graças aos quais, contra os quais) eles se formaram. A genealogia não pretende recuar no tempo para reestabelecer uma grande continuidade para além da dispersão do esquecimento; sua tarefa não é a de mostrar que o passado ainda está lá, bem vivo no presente, animando-o ainda em segredo, depois de ter imposto a todos os obstáculos do percurso uma forma delineada desde o início. Um segundo procedimento é a análise da emergência, na qual nos preocupamos com os estados de forças que marcam o aparecimento de um conceito, ao invés de assinalar o momento final de um processo. Para Foucault (2015) emergência significa o ponto de surgimento, trata-se do princípio, a lei singular de um aparecimento.

A genealogia restabelece os diversos sistemas de submissão, não a potência antecipadora de um sentido, mas sim o jogo casual das dominações. Sobre a pesquisa genealógica, pode-se dizer que, em termos metodológicos, não há um manual que oriente como realizar a pesquisa. Talvez a maneira mais produtiva seja analisar como Foucault e Nietzsche conduziram suas próprias investigações e com base nelas conduzirmos nossas pesquisas. Com a inspiração da genealogia proposta por Foucault, é dos conceitos apresentados acima que esta pesquisa foi realizada. 
Assim, buscamos identificar e analisar as condições que tornaram possível o aparecimento do livro didático de Filosofia nos anos 1980 e 1990 no Brasil. Voltamos nossa atenção para a proliferação dos acontecimentos, para a multiplicidade de forças em jogo naquele processo histórico.

\section{Resultados e Discussões}

Em dezembro de 1961 ocorreu um acontecimento decisivo para a expansão do mercado editorial do livro didático no Brasil: foi aprovada a Lei de Diretrizes e Bases da Educação Nacional - Lei 4.024/61. A nova lei possibilitou a expansão da rede pública de ensino, e um enorme contingente de crianças e adolescentes, até então distantes da escola, a ela foram encaminhados. A partir de então o número de matriculados no segundo grau quase triplicou, enquanto dobraram os do primário e do ensino superior e "[...] como consequência, em meados de 1968 já estavam à venda no Brasil, cerca de 2500 títulos didáticos distribuídos entre os três níveis, publicados por cerca de sessenta editoras” (Paixão, 1996, p. 157).

$\mathrm{Na}$ década de 1960, com as mudanças aprovadas na Lei 4.024/61 e com o aumento significativo de alunos matriculados, cresceu também a procura por livros didáticos em todo o país. Esse fato possibilitou a produção e a distribuição de livros didáticos nas diferentes disciplinas inclusive os de Filosofia. Entre 1969 e 1973, houve "[...] aparelhamento material de alcance nacional, possível na década de 70" (Rigue, Oliari, Sturza, Tomazzeti \& Veiga, 2020, p. 08), o que veio combinado com a triplicação da produção anual de livros, colocando o Brasil no ranking dos dez maiores produtores do mundo. Esse desenvolvimento promoveu transformações relevantes no setor, como o surgimento de várias editoras, algumas operando fora do eixo Rio-São Paulo e a ampliação da publicação de autores nacionais. No entanto, a grande explosão se deu no segmento de livros didáticos que ultrapassou a casa dos 100 milhões de exemplares por ano, representando mais da metade do mercado (Paixão, 1996).

Embora encontremos livros didáticos de Filosofia e/ou traduções de livros didáticos estrangeiros nesse período, em nossa pesquisa nos detivemos no estudo das décadas de 1980 e 1990. Esse período contou com vários embates de força acerca do livro didático de Filosofia, resultantes de políticas educacionais próprias das definições políticas e econômicas assumidas. Nesse cenário, o golpe militar de 1964 ocasionou profundas alterações na sociedade brasileira, não só referentes ao campo político, mas também à estrutura do ensino proposto pelo Ministério da Educação (MEC). A Ditadura Militar reestruturou as forças políticas do poder, abrindo um espaço para os norte-americanos em nossa economia, em nossa política e, também, em nossa educação (Pina, 2008). Os moldes educacionais decorrentes das novas relações políticas, sociais e econômicas, no âmbito interno, definiram o novo modelo de desenvolvimento, expressão da reordenação das formas de controle social e político, orientada pelos americanos para a modernização tecnológica e burocrática da sociedade brasileira (Pina, 2008). A educação estava marcadamente a serviço dos interesses econômicos.

Aliou-se a militarização de todo país a ajuda externa, principalmente nos setores da economia, da política e da educação, neste consolidada em acordos assinados entre o MEC e seus órgãos e a Agência Norte Americana para o desenvolvimento Internacional (USAID); desses acordos instituíram a assistência e a cooperação financeira para a organização do sistema educacional brasileiro, que deveria ajustar-se no novo modelo de desenvolvimento econômico e à política do país (Cartolano, 1985, p. 70).

Sendo assim, o ensino de segundo grau passou a ser visto de maneira instrumental e não mais como um período formador; apenas como uma etapa preparatória para a universidade (Chauí, 2018). Por sua vez, a universidade foi considerada uma garantia para a ascensão social de uma classe média que, desprovida de poder econômico e político, dava sustentação ideológica à ditadura e precisava ser recompensada. Cartolano (1985) afirma que os Acordos entre o Ministério da Educação e a United States Agency for International Development (MEC-USAID) visavam a internalização de valores culturais norte- 
americanos, através da educação. Sua influência se fez presente desde a organização do sistema educacional até as propostas de currículos dos diversos níveis de ensino, que, na época, precisavam ser modernizados. Essa suposta modernização implicava, entre outros aspectos, na valorização das áreas tecnológicas, com predominância do treinamento específico, em detrimento da formação geral e da gradativa perda de status das humanidades e ciências sociais.

Além das perseguições e do banimento de professores e de intelectuais brasileiros, que reagiram de forma contrária à Ditadura, a Filosofia e a Sociologia, disciplinas que, conforme Cartolano (1985), são genuinamente distanciadas dos saberes técnicos - foram o foco desse investimento. O reconhecimento de sua tarefa reflexiva e crítica levou, pouco a pouco, à sua exclusão do currículo nos vários níveis de formação escolar do Brasil. Gradativamente não foram toleradas disciplinas que propiciavam a análise da conjuntura do país. Com a reforma de ensino realizada em 1971, com a Lei 5.692/71, que fixou Diretrizes e Bases para o ensino de $1^{\circ}$ e $2^{\circ}$ graus, e deu outras providências, o ensino profissionalizante assumiu centralidade (Cartolano, 1985). No lugar ocupado pela Filosofia e pela Sociologia foram inseridas disciplinas que tinham como objetivo cultuar a pátria Educação Moral e Cívica, Organização Social e Política do Brasil.

O ensino da Filosofia, em grande medida, ficou recluso no interior das universidades, cenário no qual se concentrou a resistência à Ditadura Militar (Silva, 2014). Instalaram-se espaços de organização estudantis, de debates acadêmicos e políticos sobre os rumos que o país estava seguindo, bem como a busca de alternativas para a retomada do estado democrático. Em todo esse contexto, o ensino de Filosofia sofreu impactos negativos: o estudo de autores considerados subversivos pela política de segurança nacional elaborada pelos militares foi extinto; diversos professores foram afastados de suas cátedras, pela aposentadoria compulsória, sem qualquer direito a defesa, salário e outras prerrogativas de um Estado de direito. Ainda assim, alguns professores de Filosofia ministraram a disciplina. Talvez isso tenha sido possível pelo fato da Ditadura não ter tido um aparato que propiciasse um controle extremo e efetivo de todas as formas de ensino (Silva, 2014). Nesse contexto,

A discussão sobre a importância do ensino de Filosofia foi sendo resgatada inicialmente às escuras, devido à repressão militar e, posteriormente, de maneira mais intensa, a partir da retomada da democracia nos anos 1980, com as manifestações em torno da volta da Filosofia aos currículos do Ensino Médio. "Nesse contexto, os debates nos departamentos de Filosofia das universidades brasileiras desempenharam um importante papel, ainda que existissem discordâncias entre eles acerca dessas questões" (Gallo, 2010, p. 339).

Após a promulgação da Lei 5.692 de 1971, que implicou a retirada da Filosofia do Segundo Grau, surgiram vários movimentos de protesto, que reivindicavam a reintrodução da Filosofia no currículo (Alves, 2002). No ano de 1975, reitera Alves (2002), foi criada a Associação de Estudos e Atividades Filosóficas, a SEAF, que conferiu um caráter mais articulado a esses movimentos. Possuía representação em quase todos os Estados brasileiros, contando com a participação de professores e estudantes de Filosofia de quase todas as Universidades do país. A SEAF promoveu encontros, atividades, debates e publicações em parceria com outras entidades nacionais para tratar de questões referentes aos problemas da Filosofia e das relações entre a Ditadura militar e a sociedade civil. A SEAF também pode ser pensada como importante força articuladora e de resistência no âmbito do ensino de Filosofia e da produção de materiais didáticos de Filosofia.

Na década de 1980, o Estado de São Paulo, apoiado pela Secretaria Estadual de Educação, inseriu a Filosofia em seu currículo do segundo grau, especialmente na capital do Estado. Ao mesmo tempo em que esse retorno era bem quisto, havia uma demanda das escolas por conteúdos de Filosofia, bem como de professores com formação adequada para lecionarem. Isso culminou em encontros estaduais de professores, que tiveram como objetivo aperfeiçoar uma metodologia para o ensino da disciplina (Santos, Leandro Filho, Baldan, 2014). Foi a partir desses eventos que novos encontros foram realizados no Departamento de Filosofia da Universidade de São Paulo (USP), dispostos a discutir propostas de planos de curso para o segundo grau (Santos, Leandro Filho, Baldan, 2014). Foram, pois, os professores das universidades, como o caso da USP, que 
auxiliaram na elaboração de programas de ensino e produziram os primeiros textos metodológicos voltados para o ensino de Filosofia.

Dalton Alves (2002) afirma que além do Estado de São Paulo, outros começaram um movimento de retorno da Filosofia a todas as escolas. No Estado da Paraíba havia alguns colégios da capital João Pessoa que contavam com a disciplina de Filosofia em sua estrutura curricular nas décadas de 1980 e 1990. Na década de 1990 esse movimento se estendeu para a cidade de Campina Grande, entre outras. Há relatos de que, nesse período, a Filosofia se fazia presente no currículo do ensino de segundo grau no Estado do Rio Grande do Sul, até mesmo em escolas de cidades do interior, como é o caso de Santa Maria.

Entre a presença e a ausência da Filosofia no currículo das escolas brasileiras nas décadas de 1980 e 1990, um recurso para o seu ensino passou a ser intensamente produzido nesse período - o livro didático de Filosofia.

Desde a década de 1980, com o retorno parcial da Filosofia aos currículos do Ensino Médio, então na condição de disciplina optativa, foram sendo publicados livros didáticos para o seu ensino. Em princípio de modo mais tímido, depois de forma mais arrojada, as editoras foram se preocupando com este filão do mercado editorial (Gallo, 2010, p. 159).

Marilena Chauí, na aula inaugural do curso de Mestrado Profissional em Filosofia (PROF-FILO), na Universidade Federal do Paraná, em abril de 2017, explicou o processo de resistência, ocorrido durante e após a Ditadura Militar, pelo retorno da Filosofia ao currículo do ensino médio (Chauí, 2017). Segundo a filósofa, na década de 1970, as associações de docentes e estudantes de todo país lutaram e resistiram pela valorização das humanidades no ensino secundário. Alguns professores organizaram a formação pedagógica dos estudantes (de graduação) e começaram a preparar materiais didáticos de Filosofia, que, até então, inexistiam no Brasil. No período de 1980 a 1990 esse embate de forças prosseguiu, tendo como um de seus objetivos principais preparar os alunos dos cursos de Filosofia para serem professores, visto que, como mencionamos anteriormente, a luta era justamente pelo retorno da Filosofia ao segundo grau. Era necessária, então, a formação de professores e não de bacharéis. Como destaca Silveira, Marilena Chauí e outros autores e autoras passaram a produzir livros didáticos, "a fim de fornecer um subsídio para a atuação do professor e um direcionamento para as abordagens a serem adotadas em sala de aula de modo que se produzisse uma aprendizagem significativa" (Chaú, 2017, p. 75).

Marilena Chauí participou dos grupos e das associações que lutaram pelo retorno da Filosofia, mas também propuseram materiais didáticos e cursos para a formação pedagógica de estudantes universitários. Ela afirma que foi nessa época que produziu uma apostila que acabou se tornando o primeiro esboço do que viria a ser o livro 'Convite à Filosofia', publicado, posteriormente, em 1994, pela editora Ática. Nessa mesma palestra, Chauí fez um relato sobre sua experiência em relação ao ensino no segundo grau, em que esteve na condição de aluna e de professora. Segundo ela, nos dois casos, a experiência era de ausência de um livro didático de Filosofia, o que a levou, então, a sua produção anos mais tarde.

$\mathrm{Na}$ época em que foi aluna do ensino secundário, relembra que os alunos anotavam o que o professor dizia durante as aulas e depois iam para a biblioteca e consultavam a bibliografia estrangeira. Como possuíam cursos de línguas, como francês, inglês, espanhol, grego e latim, conseguiam consultar os livros no idioma de publicação e complementar as aulas. Para a Chauí, a partir do momento em que houve a democratização do ensino e a expansão da escola, houve barreiras que dificultavam o acesso a uma compreensão de filosofia europeia, o que provocou a necessidade de materiais didáticos que dissolvessem os privilégios sociais e atendessem às necessidades dos jovens estudantes das camadas populares que começavam a chegar no segundo grau. Era preciso garantir que os jovens professores tivessem um material didático mínimo, e foi, então, que a editora Ática propôs, segundo ela, a publicação de um livro didático de Filosofia; surgia assim o livro 'Convite à Filosofia' (1994). 
No ano 1980 foi publicada por editoras brasileiras uma série de livros didáticos de Filosofia, entre eles: 'Filosofando Introdução à Filosofia', das autoras Maria Helena Pires Martins, Maria Lúcia Arruda Aranha, em 1986, pela editora Moderna; 'Curso de Filosofia', de Antonio Rezende, 1986, pela editora Zahar; 'Aprendendo Filosofia', de César Aparecido Nunes, 1987, pela editora Papirus; e 'Introdução ao Estudo da Filosofia', de Antônio Xavier Teles, 1989, pela editora Ática.

Esse foi um período fértil para a expansão das discussões acerca do livro didático em geral, no Brasil. Autores como Molina (1987), Oliveira (1984) e Freitag, Motta e Costa (1989) se debruçaram sobre temas como as políticas públicas da época relacionadas ao livro didático, sobre seu uso em sala de aula, sobre a questão ideológica do livro didático e, também, sobre a importância do livro didático na sala de aula. Por isso, o livro didático emergiu com força e importância no contexto escolar brasileiro. O crescimento das discussões em torno do livro didático em grande medida foi suscitado pelo processo de redemocratização que ocorria no Brasil e também pelo surgimento do Programa Nacional do Livro Didático (PNLD), iniciado em 19 de agosto de 1985 pelo Decreto n 91.542, que substituiu o Programa do Livro Didático para o Ensino Fundamental, do Instituto Nacional do Livro (PLIDEF/INF), que vigorou entre 1971 e 1976.

O PNLD, na época, tinha como função avaliar, indicar, comprar e distribuir livros didáticos para as escolas públicas. O governo brasileiro traçou uma política pública de ação educacional e impulsionou a busca pela qualidade deste material didático, uma vez que, os livros que não estivessem adequados às propostas oficiais de ensino, não seriam indicados, diminuindo, assim, seu público e lucro (Freitag, Motta, Costa, 1989). Nesse período, décadas de 1980 e 1990, os livros didáticos de Filosofia não faziam parte do PNLD, pois o programa era destinado apenas ao ensino fundamental.

A Constituição Federal de 1988, também conhecida como Constituição Cidadã, foi um marco na história da redemocratização do país. Vale ressaltar que a Carta Magna de 1988 foi uma constituição promulgada, ou seja, contou com a participação popular em sua elaboração. Os principais pontos que pretendiam garantir democracia e justiça social eram a garantia do direito de livre manifestação do pensamento e liberdade de expressão, eleições diretas, definição do presidencialismo como sistema de governo e pontos relacionados à educação.

Nela a educação é descrita como um direito fundamental, estabelecido no artigo $6^{\circ}$, que dispõe: "Art. $6^{\circ}$ São direitos sociais a educação, a saúde, a alimentação, o trabalho, a moradia, o lazer, a segurança, a previdência social, a proteção à maternidade e à infância, a assistência aos desamparados, na forma desta Constituição" (Brasil, 1988). A temática da educação, como direito fundamental, é tratada entre os artigos 205 a 214. A Constituição estabelece a educação como um direito de todos e dever do Estado e da família, sendo promovida e incentivada com a colaboração da sociedade, visando o pleno desenvolvimento da pessoa, seu preparo para o exercício da cidadania e sua qualificação para o trabalho.

Quanto ao dever do Estado com a Educação será efetivado mediante a garantia de: educação básica obrigatória e gratuita dos quatro (4) aos dezessete (17) anos de idade, assegurada inclusive sua oferta gratuita para todos os que a ela não tiveram acesso na idade própria; progressiva universalização do Ensino Médio gratuito. Atendimento educacional especializado aos portadores de deficiência, preferencialmente na rede regular de ensino. Educação infantil, em creche e pré-escola, às crianças até cinco anos de idade. Acesso aos níveis mais elevados do ensino, da pesquisa e da criação artística, segundo a capacidade de cada um; oferta de ensino noturno regular, adequado às condições do educando e ao atendimento ao educando, em todas as etapas da educação básica, por meio de programas suplementares de material didático escolar, transporte, alimentação e assistência à saúde (Brasil, 1988). (grifo nosso)

Dessa forma, alguns programas assistenciais foram estabelecidos pelo governo como possibilidade de cumprir com os deveres pré-estabelecidos na Constituição Federal de 1988, com vistas a colocar no horizonte um ideal de igualdade em termos educacionais, como é também o propósito do PNLD. 
Molina (1987), Oliveira (1984) e Freitag, Motta e Costa (1989), que estudaram a temática do livro didático nos anos 1980, destacam exatamente a relação deste material didático amparado por programas assistenciais, tendo em vista a promessa de um processo de redemocratização da educação.

A importância dada pelo governo ao livro didático e o controle crescente sobre ele, exercido pelo governo federal, pelos estados e municípios, decorrem da percepção de que é necessário compensar - via políticas públicas - as desigualdades criadas por um sistema econômico e social injusto, com enormes discrepâncias socioeconômicas entre ricos e pobres (Freitag, Motta, Costa, 1989, p. 19).

A partir dos anos 1990, a educação no Brasil passou a ter uma nova configuração, na medida em que o governo passou a dedicar maior atenção ao ensino fundamental. Fato esse que estava ocorrendo não só no Brasil, mas em outros países, devido aos eventos propostos pela Organização das Nações Unidas para a Educação, a Ciência e a Cultura (UNESCO) (Frigotto \& Ciavatta, 2003). Tais eventos, como é o caso da Conferência Mundial sobre Educação para Todos, realizada em Jomtien, na Tailândia, no ano de 1990, que propôs a discussão de problemas relacionados à Educação mundial, principalmente no que diz respeito à alta taxa de analfabetismo no mundo e, também, para propor soluções e metas a serem cumpridas, principalmente pelos países com os piores indicadores educacionais. Conforme Lima \& Ciasca (2020):

[...] o século XIX representou uma importante ruptura e redimensionamento da educação, a escola se expandiu passando a ser gratuita, laica, obrigatória e pública. Coma democratização do ensino, as matrículas escolares aumentaram consideravelmente, necessitando de um maior número de livros didáticos para atender às escolas, tendo o governo a incumbência de subsidiar esse recurso (p. 05).

Nesse sentido, ocorreram algumas das principais mudanças educacionais da década, destacadas por Dambros e Mussio (2014). Conforme as autoras, no início dos anos 1990, o então presidente Fernando Collor de Mello (1990-1992), que tinha como projeto modernizar o país, criou dois programas: Programa Nacional de Material Escolar e o Plano Nacional de Alfabetização e Cidadania. Todavia, estes não atingiram os resultados esperados. Já no governo de Itamar Franco (1992-1994), iniciaram-se mudanças importantes como a descentralização da gestão e o aprofundamento da política de acesso universal à educação, assim como um maior investimento no setor. Fernando Henrique Cardoso (1995-1998 e 1999-2002), com a experiência adquirida nos dois governos anteriores, desenvolveu políticas públicas para a educação com a criação de programas como o Plano Nacional de Educação (PNE) e o Fundo de Manutenção e Desenvolvimento do Ensino Fundamental (FUNDEF). Um dos principais resultados positivos da época foi a redução da taxa de repetência e de evasão escolar, redução dos índices de analfabetismo e a elevação dos anos de estudo da população.

A Lei 9.394 de 20 de dezembro de 1996 estabeleceu as diretrizes e bases da educação nacional; ampliou os direitos educacionais, a autonomia de ação das redes públicas, das escolas e dos professores e deixou mais claras as atribuições dos professores (Cerqueira, Cerqueira, Souza, Mendes, 2009). As discussões sobre uma nova lei que orientasse a educação brasileira tiveram início em 1988, durante o processo de aprovação da Constituição, que deu aos municípios a atribuição de oferecer o ensino básico à população. De maneira inovadora para a época, não foi o Executivo que iniciou as discussões, e sim um grupo de educadores. De certa forma, a lei foi construída através de um viés democrático, através de congressos e fóruns, o que era um avanço para a época. Cerqueira, Cerqueira, Souza, Mendes (2009) afirmam que o texto, discutido durante oito (8) anos no Congresso, não gerou consenso por ser considerado muito detalhista, o que poderia dificultar seu cumprimento e, consequentemente, as modificações na educação brasileira.

A tramitação do projeto chegou a ser interrompida; o então senador Darcy Ribeiro (Partido Democrático Trabalhista (PDT) do Rio de Janeiro (RJ)) apresentou uma nova versão reescrita de modo mais aberto e conciso, a qual foi aprovada. Ela 
não abrangeu todas as especificidades que estavam na primeira versão, mas conseguiu, de certa forma, contemplar a realidade educacional do país. Sobre o ensino da Filosofia, o art. 36 da LDB de 1996 assegurou a presença de conteúdos filosóficos no ensino médio, porém não estipulou a sua obrigatoriedade. De acordo com Gallina (2000), mesmo não afirmando em nenhum momento a importância do ensino da Filosofia para o ensino médio, pelo menos como disciplina na grade curricular básica e na apresentação de possíveis resultados, aparece expresso que o educando deve possuir domínio dos conhecimentos de Filosofia e Sociologia e também os conhecimentos necessários para o exercício da cidadania, como é possível ver abaixo.

Art. $361^{\circ}$ Os conteúdos, as metodologias e as formas de avaliação serão organizados de tal forma que ao final do Ensino Médio o educando demonstre: [...] III - domínio dos conhecimentos de Filosofia e de Sociologia necessários ao exercício da cidadania (Brasil, 1996).

Do ponto de vista de Montero (2014), a Filosofia passou, então, a ter uma "presença inócua" no currículo da educação secundária, já que a lei, apesar de afirmar que os educandos devem apresentar, ao final do ensino médio, conhecimento de Filosofia e Sociologia, não define a obrigatoriedade de suas disciplinas.

Presença inócua, porque o discurso da importância da Filosofia não se traduz em uma presença efetiva dessa disciplina nos currículos do ensino médio. Por um lado. A necessidade da Filosofia está presente na lei, mas, ao analisarmos mais atentamente, percebemos que não nos é possível afirmar com precisão como se dá a inclusão da Filosofia no currículo do Ensino Médio, se como uma disciplina obrigatória, ou se a Filosofia deve ser trabalhada de forma transversal em outras disciplinas (Montero, 2014, p.27).

Poucos meses após a promulgação da Lei 9.394/1996, o então deputado federal Padre Roque Zimmermann (Partido dos Trabalhadores (PT) do Paraná (PR)), apresentou o projeto de Lei n 3.178, de 28/05/1997. O referido projeto propunha a alteração do artigo 36 da Lei n 9.394/96, para que a Filosofia e a Sociologia se tornassem disciplinas obrigatórias no ensino médio. Vale ressaltarmos que esse projeto começou a tramitar no ano de 1997.

Por aproximadamente três anos, tramitou na Câmara e no Senado Federal um projeto de lei complementar que substituiria o artigo 36 da LDB, definido a obrigatoriedade das disciplinas de Filosofia e Sociologia nos currículos do Ensino Médio. Após a aprovação do projeto nessas duas instâncias do Poder Legislativo Federal, ele foi vetado, em outubro de 2001, pelo então presidente Fernando Henrique Cardoso (Montero, 2014, p. 29).

Em um primeiro momento, o Projeto de Lei obteve parecer favorável na Comissão de Educação Cultura e Desporto (CECD), encarregada da análise do mérito e da avaliação e apreciação inicial dele. A Comissão de Constituição e Justiça (CCJ), encarregada da apreciação da juridicidade, constitucionalidade e técnica legislativa, também aprovou o Projeto de Lei. Esse poder terminativo exercido pelas comissões dispensou seu trâmite pelo Plenário da Câmara dos deputados, sendo que, imediatamente após a apreciação destas comissões, o Projeto de Lei foi encaminhado ao Senado Federal, em 13 de abril de 2000.

Os trâmites pelo Senado Federal seguiram os rituais de praxe e, através das comissões de Educação e de Justiça e dos Senadores José Fogaça e Álvaro Dias, foram apresentados pareceres favoráveis à aprovação da obrigatoriedade da inclusão da Filosofia e da Sociologia nos currículos do ensino médio. Várias mobilizações da comunidade acadêmica e educacional fizeram com que o projeto de reintrodução das disciplinas de Filosofia e Sociologia fosse aprovado, tanto na Câmara dos Deputados como no Senado Federal. Em setembro de 2001, após ser aprovado na Câmara por unanimidade, o Projeto de Lei do Padre Roque foi aprovado no plenário por quarenta (40) votos a favor e vinte (20) contra, e foi à sanção presidencial.

Contudo, o projeto apresentado por Padre Roque Zimmermann foi vetado pelo Presidente Fernando Henrique Cardoso, alegando que uma alteração dessa natureza implicaria um esforço orçamental e que o número de professores 
formados nessas disciplinas era insuficiente para fazer frente às novas exigências (Montero, 2014). Para além disso, o governo continuou a acreditar que os conhecimentos filosóficos tratados transversalmente durante o ensino médio chegariam para complementar os propósitos de natureza cívica previamente estipulados.

Os argumentos que sustentaram o veto foram basicamente dois (...) a) a inclusão das disciplinas de Filosofia e Sociologia implicaria incremento orçamentário impossível de ser arcado pelos estados e municípios; b) não haveria suficientes professores formados para fazer às novas exigências da obrigatoriedade da disciplina (Fávero, Ceppas, Gontijo, Gallo \& Kohan, 2004, p. 260).

Ao realizar a leitura da Mensagem n 1.073, de 8 de outubro de 2001, de Fernando Henrique Cardoso, enviada ao presidente do Senado Federal, podemos perceber que boa parte dos argumentos que se opõem à criação de um espaço obrigatório de disciplinas para o ensino de Filosofia não são de ordem pedagógica, epistemológica ou de políticas educacionais. Para Montero (2014), tais argumentos são basicamente de natureza burocrática e giram em torno do fato de que o resultado imediato será a necessidade de abrir concurso para contratar professores para a escola pública, o que iria gerar muitas despesas. Nesse sentido, caracterizou-se como uma questão econômica, ou seja, as razões do veto foram procedimentais e centradas na ideia de que não haveria professores para assumir essas aulas, e que isso significaria uma despesa excessiva.

O único argumento e ordem pedagógica usado para justificar o veto foi dado pelo então ministro da Educação, Paulo Renato Souza, que defendia que a volta das duas disciplinas seria uma volta ao passado, pois a proposta representava um retrocesso no perfil curricular do Ensino Médio, que a partir da LDB/96 passou a valorizar a interdisciplinaridade no lugar das disciplinas estanques (Montero, 2014, p. 65).

Após o projeto, que visava o retorno da obrigatoriedade do ensino de Filosofia e Sociologia no ensino médio, ser apresentado no ano de 1997, o governo de Fernando Henrique Cardoso reagiu à proposta legislativa com um Parecer elaborado pela então conselheira Guiomar Namo de Mello (Partido da Social Democracia Brasileira (PSDB), do Conselho Nacional de Educação (CNE). No dia 1 de junho, foi aprovado no CNE o Parecer CNE/CEB (Conselho da Educação Básica) n 15/9816 que tratava minuciosamente, pela conselheira, sobre as Diretrizes Curriculares para o Ensino Médio, as quais foram instituídas pela resolução CNE/CEB n. ${ }^{\circ}$ 03/98 aprovada no dia 26 de junho.

No artigo 10, incisos I, II e III, explicitou-se a organização e estruturação do currículo do ensino médio, não mais em disciplinas, mas em áreas de conhecimento. Foram definidas três grandes áreas para esse nível de ensino: Ciências da Natureza, Matemática e suas Tecnologias; Linguagens, Códigos e suas Tecnologias; Ciências Humanas e suas Tecnologias (Brasil, 1998). O parágrafo $1^{\circ}$ do artigo $9^{\circ}$ afirma que: "A base nacional comum dos currículos do ensino médio deverá contemplar as três áreas do conhecimento, com tratamento metodológico que evidencie a interdisciplinaridade e a contextualização" (Brasil, 1998). No parágrafo $2^{\circ}$ do mesmo artigo, afirma-se que:

$\S 2^{\circ}$ As propostas pedagógicas das escolas deverão assegurar tratamento interdisciplinar e contextualizado para: a) Educação Física e Arte, como componentes curriculares obrigatórios; b) Conhecimentos de Filosofia e sociologia necessários ao exercício da cidadania (Brasil, 1998). (Grifo nosso)

Sendo assim, podemos perceber que os documentos não excluem de forma categórica o ensino disciplinar, no entanto, vê-se uma preferência transversal de currículo, a qual garantiria, em tese, o cumprimento do previsto na Lei 9.394/1996 quanto à necessidade de domínio de conhecimentos de Filosofia e Sociologia. Podemos compreender, então, que existe uma dubiedade entre as afirmações da desta Lei e das referidas Diretrizes, dado que, ao mesmo tempo em que a primeira afirma que existem conhecimentos de Filosofia e Sociologia necessários ao exercício de cidadania, as Diretrizes atribuem para essas duas disciplinas um caráter de transversalidade e interdisciplinaridade. 
Vale lembrarmos que o artigo 36, § $1^{\circ}$, inciso III, da Lei 9.394/1996, afirma:

$\S 1^{\circ}$ Os conteúdos, as metodologias e as formas de avaliação serão organizadas de tal forma que ao final do Ensino Médio o educando demonstre: III - domínio dos conhecimentos de Filosofia e Sociologia necessários ao exercício da cidadania (Brasil, 1996).

Em contraposição, o artigo 10 da Resolução CNB/CEB nº 3/98, fundamentada no Parecer CNE/CEB nº 15/98, afirma: “ $2^{\circ}$ As propostas pedagógicas das escolas deverão assegurar tratamento interdisciplinar e contextualização para: b) Conhecimentos de Filosofia e Sociologia ao exercício da cidadania” (Brasil, 1998). Fica claro que os conteúdos da Resolução CNE/CEB no 03/98 negam a obrigatoriedade do ensino de Sociologia e Filosofia no ensino médio, com base em uma interpretação neoliberal da própria LDB. O Parecer CNE/CEB nº 15/98 destaca, diversas vezes, que a principal função do ensino médio é a preparação para o trabalho e que é este que dá significado às aprendizagens da escola de ensino médio. É interessante ressaltarmos que um dos papéis atribuídos pela retórica neoliberal à educação é a de atrelar a educação à preparação para o trabalho, e a pesquisa acadêmica ao imperativo do mercado ou às necessidades da livre iniciativa (Montero, 2014). O que permite considerar que existiam diferentes tônicas para pensar a presença da Filosofia e da Sociologia no ensino médio.

De modo geral, conforme a expansão da rede escolar no período entre 1980 e 1990, e da necessidade da formação em cursos de licenciatura, o consumo de livros didáticos aumentou e alcançou enormes tiragens. Alguns livros didáticos de Filosofia foram publicados na década de 1990, sucedendo os livros já publicados nos anos de 1980.

Entre os livros didáticos de Filosofia que foram lançados no período dos anos 1990, destacamos os seguintes: 'Filosofia para iniciantes', de Richard Osborne, ilustrado por Ralph Edney, editora Objetiva, 1991; 'Filosofia: Iniciação à investigação Filosófica', de José Auri Cunha, de 1992, da editora Alinea/Atual; 'Introdução à Filosofia: Aprendendo a Pensar', de Cipriano Luckesi e Elizete Passos, do ano de 1992 (2ª edição), do Centro Editorial Didático (Bahia) Cortez; 'Filosofia para Principiantes', de Arcângelo Buzzi, editora Vozes, 1994; 'Convite à Filosofia', de Marilena Chaú́, no ano de 1994, pela Editora Ática; 'Pensando Melhor - Iniciação ao Filosofar', de Angélica Sátiro e Ana Miriam Wuensch, 1995, editora Saraiva; 'Para Filosofar' de Cordi e outros autores, 1995, Editora Scipione; 'Ética e Cidadania Caminhos da Filosofia', de Sílvio Gallo, 1997, Papirus Editora; e ‘Temas de Filosofia’, de Maria Helena Pires Martins e Maria Lúcia Arruda Aranha, 1998, Moderna.

Dessa forma, o livro didático de Filosofia passou a ser intensamente produzido no Brasil. Desde o final do século passado, o livro didático desempenha importante papel no setor editorial, mas foi necessário um longo processo até que alcançasse um papel de destaque. Os acontecimentos no período estudado se constituíram como condições para a emergência do livro didático de Filosofia no Brasil.

\section{Considerações Finais}

A emergência do livro didático de Filosofia é resultado de forças em jogo que se tramaram nos seguintes períodos: o fim da Ditadura Militar; o processo de redemocratização (1980); o processo de massificação do ensino (1990); as lutas e os embates para o retorno do ensino de Filosofia aos currículos do segundo grau/ensino médio e a publicação da Lei 9.349 de 1996. Por isso, entendemos, com Foucault (2015), que um acontecimento histórico nunca deve ser tomado a partir de um ponto de origem, que se encaminha para um ponto final, mas como episódio atual em toda uma série de sujeições e submissões que não se encerra e, portanto, permanecerá em luta, resultando em outros surgimentos.

A presença dos livros didáticos no Brasil é cada vez maior dentro das instituições escolares, em virtude, principalmente, da criação de Programas Nacionais para o Livro Didático. Contudo, é importante destacar que, neste estudo, 
houve um recorte específico quanto às décadas de 1980 e 1990. Por isso, embora não seja ênfase do estudo os acontecimentos posteriores a esse recorte temporal, enfatizamos que tudo que emergiu após a década de 1990, no que tange ao livro didático de filosofia, é devedor das forças apresentadas neste estudo.

Por isso entendemos ser importante compreender a emergência e relevância dos livros didáticos de filosofia nas décadas indicadas, ao mesmo tempo em que ele serve de subsídio para estudos posteriores, como pode ser traçado em pesquisa futura que olhe para o que foi produzido antes desse recorte temporal, bem como outros materiais impressos utilizados para o ensino da filosofia, tais como: compêndios, enciclopédias, livros clássicos e manuais.

\section{Referências}

Alves, D. J. (2002). A Filosofia no ensino médio: ambiguidades e contradições na LDB. C Autores Associados.

Brasil. (1988). Constituição da República Federativa do Brasil. Brasília: DF. http://www.planalto.gov.br/ccivil_03/constituicao/constituicao.htm.

Brasil. (1996). Lei no 9.394, de 20 de dezembro de 1996. Estabelece as diretrizes e bases da educação nacional. Diário Oficial da União: seção 1, Brasília, DF. http://www.planalto.gov.br/ccivil_03/leis/19394.htm.

Cartolano, M. T. P. (1985). Filosofia no ensino de $2^{\circ}$ grau. Cortez Autores Associados.

Cerqueira, A. G., Cerqueira, A. C., Souza, T. C., \& Mendes, P. A. (2009). A trajetória da LDB: um estudo crítico frente à realidade brasileira. In: Ciclo de estudos históricos. (2009). Anais. Ilhéus: CEAP.

Chauí, M. (2017, April 10). Aula Inaugural com Marilena Chauí [Web page]. https://www.youtube.com/watch?v=yAq7oyrvo1E.

Chauí, M. (2018). Em defesa da educação pública, gratuita e democrática. Autêntica Editora.

Cunha, L. A. (2014). Ensino profissional: o grande fracasso da ditadura. Cadernos de Pesquisa, 44(154), 912-93. http://publicacoes.fcc.org.br/ojs/index.php/cp/article/view/2913/pdf_9.

Dambros, M., \& Mussio, B. R. (2014). Política educacional brasileira: a reforma dos anos 90 e suas implicações. In: Anped Sul, Anais [...]. Florianópolis: UDESC.

Fávero, A. A., Ceppas, F., Gontijo, P. E., Gallo, S. \& Kohan, W. O. (2004). O ensino da filosofia no Brasil: um mapa das condições atuais. Caderno Cedes, 24(64), 257-284. https://www.scielo.br/pdf/ccedes/v24n64/22830.pdf.

Fico, C. (2004). Versões e controvérsias sobre 1964 e a ditadura militar. Revista Brasileira de História, 24(47), 29-60. https://www.scielo.br/pdf/rbh/v24n47/a03v2447.pdf.

Foucault, M. (2015). Microfísica do poder. Paz e Terra.

Freitag, B., Motta, V. R. \& Costa, W. F. (1989). O livro didático em questão. Cortez Autores Associados.

Frigotto, G. \& Ciavatta, M. (2003). Educação Básica no Brasil na década de 1990: subordinação ativa e consentida à lógica do mercado. Educação \& Sociedade, 24(82), 93-130. https://www.scielo.br/scielo.php?pid=S0101-73302003000100005\&script=sci_abstract\&tlng=pt.

Gallina, S. (2000). A disciplina de Filosofia e o Ensino Médio. In: Gallo, S.; Kohan, W. O. (Orgs.). Filosofia no Ensino Médio. Petrópolis: Vozes, 34-46.

Gallo, S. (2010). Ensino de Filosofia e materiais didáticos. In: Cornelli, G.; Carvalho, M.; \& Danelon, M. (Coord.). Filosofia: ensino médio. Brasília: Ministério da Educação/Secretaria da Educação Básica, 159-170.

Lima, N. R. \& Ciasca, M.I.F.L. (2020). História da avaliação pedagógica do livro e material didático no Brasil. Pesquisa, Sociedade e Desenvolvimento, 9 (3), e90932509. https://doi.org/10.33448/rsd-v9i3.2509

Molina, O. (1987). Quem engana quem? Professor x livro didático. Papirus.

Oliveira, J. B. A. \& Guimarães, S. D. P. (1984). A política do livro didático. UNICAMP.

Paixão, F. (1996). Momentos do livro no Brasil.: Ática.

Pina, F. (2008). Acordo MEC-USAID: ações e reações (1966-1968). In: Encontro Regional de História: poder, violência e exclusão. Anais [...]. ANPUH/SPUSP.

Rigue, F. M., Oliari, G., Sturza, R. B., Tomazzeti, E. M. \& Veiga, A. M. da R. (2020). Amateur teacher: contrasting possibilities with teacher education in Brazil. Research, Society and Development, 9(2), e34922000. https://doi.org/10.33448/rsd-v9i2.2000

Rigue, F. M. (2020). Uma Genealogia da Formação Inicial de Química no Brasil. (Tese de Mestrado, Universidade Federal de Santa Maria, Santa Maria, Brasil). https://repositorio.ufsm.br/handle/1/19926. 
Research, Society and Development, v. 10, n. 3, e11510313047, 2021 (CC BY 4.0) | ISSN 2525-3409 | DOI: http://dx.doi.org/10.33448/rsd-v10i3.13047

Rodrigo, L. M. (2009). Filosofia em sala de aula: teoria e prática para o ensino médio. Campinas: Autores Associados.

Santos, G. S., Leandro Filho, J. A. \& Baldan, A. S. (2014). O itinerário da Filosofia no currículo do Ensino Médio do Estado de São Paulo. Revista da Faculdade de Educação da Universidade do Estado de $\quad$ Mato $22(2), \quad$ Grosso, http://www2.unemat.br/revistafaed/content/vol/vol_22/artigo_22/69_80.pdf.

Silva, L. H. P. (2014). A universidade e o cinquentenário do golpe civil-militar de abril de 1964. In: Valle, M. R. (Org.). Golpe militar, história, memória, e direitos humanos. Cultura Acadêmica, 63-89.

Silveira, T. C. (2015). Ensino de Filosofia no Ensino Médio: uma análise do livro iniciação à Filosofia de Marilena Chauí. Cadernos do PET Filosofia, 6(110, 75-92. https://revistas.ufpi.br/index.php/pet/article/view/3655/2767.

Sturza, R. B. (2019). Livros didáticos de filosofia no Brasil (1980-1990): Um estudo sobre proveniências e modos de ensinar filosofia. (Dissertação de Mestrado, Universidade Federal de Santa Maria, Santa Maria, Brasil). https://repositorio.ufsm.br/handle/1/18957. 